\title{
ALIH FUNGSI LAHAN PERTANIAN DI KABUPATEN MINAHASA UTARA
}

\author{
Yuniarti Amelhia Lapatandau \\ Grace A. J. Rumagit \\ Caroline B.D. Pakasi
}

\begin{abstract}
This study aims to find out how the conversion of agricultural land in 2013 to 2016 in North Minahasa District. The study was conducted from February to June 2017. The data used were secondary data obtained from North Minahasa National Land Agency (BPN) and Central Bureau of Statistics (BPS) of North Sulawesi. Data analysis used is descriptive data analysis method by using tables and graphs to describe conversion of agricultural land in Kabupaten Minahasa Utara. Analysis of the data taken is expert report of agricultural land function in North Minahasa District from 2013 to 2016. The results show that land conversion in North Minahasa District from 2013 to 2016 tends to increase. With increasing of farming land conversion means increasingly narrow agricultural land, while land conversion increases.
\end{abstract}

Keyword: conversion, farmland, North Minahasa District

\begin{abstract}
ABSTRAK
Penelitian ini bertujuan untuk mengetahui bagaimana konversi lahan pertanian pada tahun 2013 sampai 2016 di Kabupaten Minahasa Utara. Penelitian dilakukan dari bulan Februari sampai Juni 2017. Data yang digunakan adalah data sekunder yang diperoleh dari Kantor Badan Pertanahan Nasional (BPN) Minahasa Utara dan Badan Pusat Statistik (BPS) Sulawesi Utara. Analisis data yang digunakan adalah metode analisis data deskriptif dengan menggunakan tabel dan grafik untuk menggambarkan konversi lahan pertanian di Kabupaten Minahasa Utara. Analisis data yang diambil adalah laporan pakar fungsi lahan pertanian di Kabupaten Minahasa Utara dari tahun 2013 sampai 2016. Hasil penelitian menunjukkan bahwa konversi lahan di Kabupaten Minahasa Utara dari tahun 2013 sampai 2016 cenderung meningkat. Dengan meningkatnya konversi lahan berarti lahan pertanian semakin sempit, sementara konvensi tanah meningkat.
\end{abstract}

Kata kunci: konversi, lahan pertanian, Kabupaten Minahasa Utara 


\section{PENDAHULUAN}

\section{Latar Belakang}

Kehidupan manusia yang semakin maju dan berkembang menuntut akan banyak hal sebagai suatu perubahan baik dari segi pembangunan dan kemajuan intelektual hal tersebut sangat perlu dilakukan untuk memenuhi setiap kebutuhan hidup manusia seperti, pertumbuhan penduduk yang terusmenerus meningkat mengharuskan pembangunan akan perumahan dan bangunan untuk tempat tinggal semakin dibutuhkan. Cara untuk memenuhi kebutuhan lahan yaitu dengan pengadaan lahan (Mokoagow, 2012). Seiring dengan peningkatan jumlah penduduk dan perkembangan struktur perekonomian, kebutuhan lahan untuk kegiatan non pertanian cenderung terus meningkat. Kecenderungan tersebut menyebabkan alih fungsi lahan pertanian sulit dihindari. Beberapa kasus menunjukkan jika disuatu lokasi terjadi alih fungsi lahan, maka dalam waktu yang tidak lama lahan disekitarnya juga beralih fungsi secara progesif. Sejalan dengan pembangunan kawasan perumahan atau industri disuatu lokasi alih fungsi lahan, maka aksebilitas dilokasi tersebut menjadi semakin kondusif untuk pengembanganindustri dan pemukiman. Lahan menjadi salah satu unsur utama dalam menunjang kehidupan manusia. Fungsi lahan sebagai tempat manusia beraktivitas untuk mempertahankan hidup dan eksistensinya. Penggunaan lahan yang meningkat oleh manusia, seperti untuk tempat tinggal, tempat melakukan usaha, pemenuhan akses umum dan fasilitas lain akan menyebabkan lahan yang tersedia semakin menyempit. Timbulnya permasalahan penurunan kualitas lingkungan nantinya akan mengganggu keseimbangan ekosistem, hal tersebut karena penggunaan, daya dukung dan perubahan bentuk peruntukan lahan.

Alih fungsi lahan merupakan kegiatan perubahan penggunaan tanah dari suatu kegiatan yang menjadi kegiatan lainnya. Alih fungsi lahan muncul sebagai akibat dari pembangunan dan peningkatan jumlah penduduk. Pertambahan penduduk dan peningkatan kebutuhan lahan untuk kegiatan pembangunan telah merubah struktur industri yang cukup pesat berakibat terkonversinya lahan pertanian secara besar-besaran. Selain untuk memenuhi kebetuhan industri, alih fungsi lahan pertanian juga terjadi secara cepat untuk memenuhi kebutuhan perumahan jumlahnya jauh lebih besar (Sasono, 1995).

Lahan selalu mengalami perubahan dari waktu ke waktu seiring meningkatnya kebutuhan manusia akan lahan. Perubahan tersebut dikarenakan memanfaatkan lahan untuk kepentingan hidup manusia. Alih fungsi lahan pertanian yang tidak terkendali apabila tidak ditanggulangi dapat mendatangkan permasalahan yang serius, antara lain dapat mengancam kapasitas lahan. Kecenderungan terus meningkatnya kebutuhan akan lahan ini menyebabkan alih fungsi lahan pertanian sulit untuk dihindari (Iqbal, 2007). Meningkatnya kebutuhan lahan untuk perkantoran, pemukiman, pabrik dan pergudangan serta pembangunan jalan juga dialami oleh Kabupaten Minahasa Utara pasca pemekaran dari Kabupaten Minahasa pada tahun 2004. Letak wilayah Kabupaten Minahasa Utara yang sangat strategis, diapit oleh dua Kota yaitu Kota Manado dan Kota Bitung yang memiliki sektor industri dan jasa yang sangat potensial sehingga membutuhkan akses jalan yang baik untuk menghubungkan kedua Kota tersebut melalui Kabupaten Minahasa Utara. Hal inilah yang membuat para investor baik domestik maupun asing, tertarik untuk melakukan investasi di daerah ini. Untuk menunjang investasi tersebut dibutuhkan lahan untuk membangun sarana dan prasarana yang akan dipakai untuk kelancaran kegiatan investasinya. Dengan adanya keterbatasan lahan di daerah ini mengakibatkan cenderung meningkatnya konversi lahan dari lahan pertanian ke non pertanian secara cepat dan progresif. Oleh karena itu, penting untuk dilakukan penelitian tentang "Alih Fungsi Lahan Pertanian di Kabupaten Minahasa Utara".

\section{Rumusan Masalah}

Berdasarkan latar belakang di atas, maka yang menjadi permasalahan dalam penelitian ini adalah bagaimana alih fungsi lahan pertanian di Kabupaten Minahasa Utara? 


\section{Penelitian ini bertujuan untuk} mengetahui luas alih fungsi lahan pertanian pada tahun 2013 hingga 2016 di Kabupaten Minahasa Utara.

Manfaat
Penelitian ini diharapkan dapat
bermanfaat untuk:
1. Memperluas wawasan serta pengetahuan
mengenai alih fungsi lahan pertanian ke
non pertanian
2. Memberikan masukan kepada pemerintah
Kabupaten Minahasa Utara tentang alih
fungsi lahan pertanian ke non pertanian di
daerah tersebut.

\section{METODOLOGI PENELITIAN}

\section{Waktu dan Tempat Penelitian}

Penelitian ini dilaksanakan selama tiga bulan dimulai dari bulan Februari hingga Mei Tahun 2017. Tempat penelitian berlokasi pada Kantor Badan Pertanahan Nasional (BPN) Kabupaten Minahasa Utara.

\section{Metode Pengumpulan Data}

Penelitian ini menggunakan data sekuder yaitu data yang dipublikasikan oleh Badan Pertanahan Nasional Kabupaten Minahasa Utara. Data yang digunakan berupa data deret waktu (time series) untuk variabel luas alih fungsi lahan pertanian dari tahun 2013 hingga 2016. Selain itu, digunakan juga data penunjang lainnya dari laman (website) dari beberapa instansi terkait dengan penelitian ini seperti Badan Pusat Statistik (BPS) Sulawesi Utara.

\section{Konsep Pengukuran Variabel}

Adapun variabel alih fungsi lahan pertanian diukur dalam satuan luas hektar (Ha) dan diuraikan berdasarkan 10 Kecamatan di Kabupaten Minahasa Utara menurut luasan yang terbesar hingga yang terkecil.

\section{Metode Analisis Data}

Data yang diperoleh dianalisis secara deskriptif menggunakan tabel, gambar dan grafik, serta menggunakan analisis tren untuk mendeskripsikan kecenderungan perkembang- an alih fungsi lahan pertanian ke non pertanian dari tahun ke tahun.

\section{HASIL DAN PEMBAHASAN}

\section{Deskripsi Umum Wilayah Penelitian}

Kabupaten Minahasa Utara merupakan kabupaten yang dibentuk berdasarkan UndangUndang Nomor 55 Tahun 2003 dan diresmikan oleh Menteri Dalam Negeri atas nama Presiden Republik Indonesia pada tanggal 7 Januari 2004. Minahasa Utara adalah salah satu Kabupaten di Provinsi Sulawesi Utara dengan ibukota Airmadidi, berjarak sekitar $35 \mathrm{~km}$ dari Manado, ibukota Provinsi Sulawesi Utara, dengan batas-batas wilayah berikut ini :

Sebelah Utara berbatasan dengan Laut Sulawesi dan Kepulauan Sangihe

Sebelah Timurberbatasan dengan Laut Maluku dan Kota Bitung

Sebelah Barat berbatasan dengan Laut Sulawesi dan Kota Manado

Sebelah Selatan berbatasan dengan Kabupaten Minahasa.

Luas wilayah Kabupaten Minahasa Utara termasuk pulau-pulaunya adalah $1.059,244 \mathrm{~km}^{2}$. Garis pantai sepanjang 292,20 $\mathrm{km}$, jumlah pulau sebanyak 46 buah. Sebagai Kabupaten yang terletak di wilayah pesisir, ada tiga kecamatan yang sebagian wilayahnya terpisah dari pulau Sulawesi, yaitu Kecamatan Wori, (Mantehage dan Nain), Kecamatan Likupang Timur (Bangka), dan Kecamatan Likupang Barat (Gangga, Talise, Kinabuhutan).

Kabupaten Minahasa Utara terdiri dari 10 kecamatan, yaitu : Kecamatan Kema, Kecamatan Kauditan, Kecamatan Airmadidi, Kecamatan Kalawat, Kecamatan Dimembe, Kecamatan Talawaan, Kecamatan Wori, Kecamatan Likupang Barat, Kecamatan Likupang Timur dan Kecamatan Likupang Selatan. Kondisi wilayah Kabupaten Minahasa Utara terdiri dari pengunungan dan berbukit, topografi ini sekaligus dapat menggambarkan keadaan wilayah Kabupaten Minahasa Utara sebagai daerah yang subur dan berpotensi besar dimasa mendatang untuk pengembangan sentrasentra produksi pertanian tanaman pangan, holtikultura, perkebunan dan kehutanan serta ditunjang oleh ketersediaan sumberdaya kelautan dan perikanan yang sangat berlimpah disamping juga memiliki basis-basis kawasan 
industri. Letak Kabupaten Minahasa Utara sangat strategis, karena berada di antara dua Kota yaitu Kota Manado dan Bitung yang memiliki gerbang utama Regional, Nasional maupun Internasional, yaitu Bandar Udara Internasional Sam Ratulangi dan Pelabuhan Bitung.

\section{Luas Lahan Pertanian Menurut Penggunaannya di Kabupaten Minahasa Utara}

Kualitas hidup masyarakat semakin hari semakin meningkat, secara otomatis mempengaruhi kebutuhan hidup manusia, sehingga pembangunan pemukiman dan pembangunan prasarana-prasarana lainnya terus bertambah. Hal ini menuntut akan adanya lahan untuk memenuhi kebetuhuan tersebut sehingga terjadinya alih fungsi lahan dari fungsi sebelumnya tidak dapat dihindari lagi. Demikian halnya di Kabupaten Minahasa Utara, alih fungsi lahan pertanian ke non pertanian cenderung meningkat. Tabel berikut ini menunjukkan luas lahan pertanian menurut penggunaannya pada Tahun 2012 hingga 2015.

Tabel 1. Luas Lahan Pertanian Menurut Penggunaannya di Kabupaten MinahasaUtara Tahun, 2012-2013-2014-2015 (Ha)

\begin{tabular}{|c|c|c|c|c|}
\hline \multirow[t]{2}{*}{ Luas Lahan } & \multicolumn{4}{|l|}{ Tahun } \\
\hline & 2012 & 2013 & 2014 & 2015 \\
\hline Irigasi Teknis & 2.877 & 2.877 & 3.330 & 3.355 \\
\hline Irigasi Setengah Teknis & - & - & - & - \\
\hline Irigasi Sederhana & - & - & - & - \\
\hline Irigasi Desa & - & - & - & - \\
\hline Tadah Hujan & 713 & 713 & 271 & 271 \\
\hline Lebak, Polder & - & - & - & - \\
\hline Tegal, Kebun & 26.189 & 26.189 & 12,297 & $\begin{array}{l}12,29 \\
7\end{array}$ \\
\hline Ladang, Huma & 2.808 & 2.808 & 5.066 & 5.066 \\
\hline Padang Rumput & 77 & 77 & 77 & 77 \\
\hline Perkebunan & 28.221 & 28.221 & 39.929 & $\begin{array}{l}39.92 \\
9\end{array}$ \\
\hline $\begin{array}{l}\text { Lahan Sementara Tidak } \\
\text { Di Usahakan }\end{array}$ & 10.348 & 10.348 & 10.089 & $\begin{array}{l}10.08 \\
9\end{array}$ \\
\hline Lahan Tanaman & 8.510 & 8.510 & 13.912 & $\begin{array}{l}13.91 \\
2\end{array}$ \\
\hline $\begin{array}{l}\text { Lainnya } \\
\text { (Tambak/Hutan } \\
\text { Negara/Rawa }\end{array}$ & 14.234 & 14.234 & 8.553 & 8.553 \\
\hline Total & 93.977 & 93.977 & 93.524 & $\begin{array}{l}93.54 \\
9\end{array}$ \\
\hline
\end{tabular}

Sumber : BPS Sulawesi Utara dalam angka dari tahun 2011-2016, 2017
Berdasarkan Tabel satu, tampak bahwa pada tahun 2013 ke 2014, terjadi penurunan yang cukup tajam pada luasan tegal atau kebun dari 26.189 menjadi 12.297 hektar atau berkurang sebesar 13.892 hektar (53,05 persen). Hal Ini terutama disebabkan oleh adanya konversi lahan tegal atau kebun menjadi lahan non pertanian seperti lahan pemukiman, pabrik dan pergudangan serta pembangunan jalan tol Manado - Bitung.

\section{Luas Alih Fungsi Lahan Kabupaten Minahasa Utara Menurut Kecamatan Tahun $2013-2016$ \\ Seiring dengan peningkatan} pembangunan berbagai infrastruktur di Kabupaten Minahasa Utara maka konsekuensinya adalah peralihan fungsi dari lahan pertanian ke non pertanian juga meningkat. Gambar 1 menunjukkan bahwa pada tahun 2013, dari 10 kecamatan yang ada di Kabupaten Minahasa Utara maka Kecamatan Kalawat menempati urutan pertama luas alih fungsi lahan pertanian ke non pertanian diikuti oleh Kecamatan Airmadidi dan Kecamatan Talawaan.

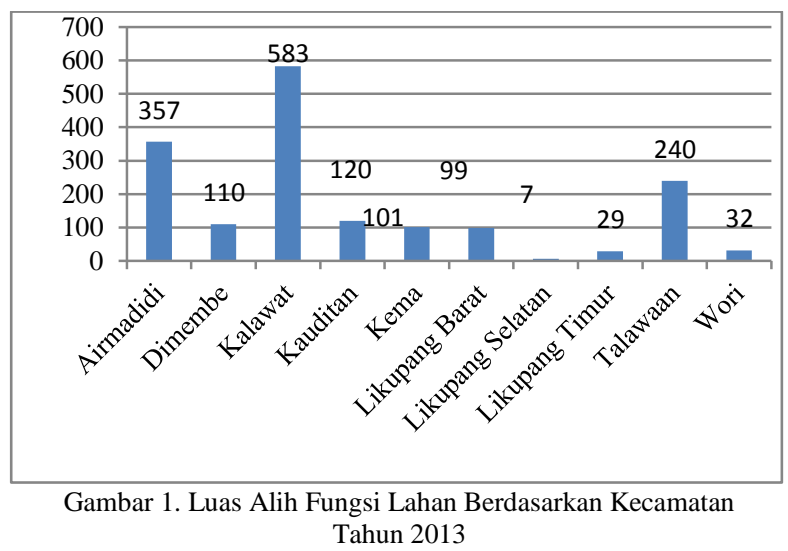

Pada tahun 2013, di Kecamatan Kalawat terdapat 583 hektar lahan pertanian yang beralih fungsi dari lahan pertanian menjadi kawasan perumahan, pabrik dan pergudangan. Sedangkan kecamatan yang paling rendah luas alih fungsi lahan adalah Kecamatan Likupang Selatan yakni hanya sebesar 7 hektar. Selanjutnya pada Gambar 2, dapat dilihat bahwa alih fungsi lahan pertanian ke non pertanian, masih tertinggi pada Kecamatan Kalawat diikuti oleh Kecamatan Airmadidi dan Kauditan. Namun yang mengalami peningkatan yang sangat signifikan adalah Kecamatan Airmadidi, pada tahun 2013 sebesar 
357 hektar meningkat sebesar 42,58 persen menjadi 509 hektar pada tahun 2014, atau terdapat 152 hektar lahan pertanian yang beralih fungsinya. Meningkatnya luas alih fungsi lahan tersebut, antara lain, karena meningkatnya target pembebasan lahan untuk pembangunan jalan tol Manado - Bitung.

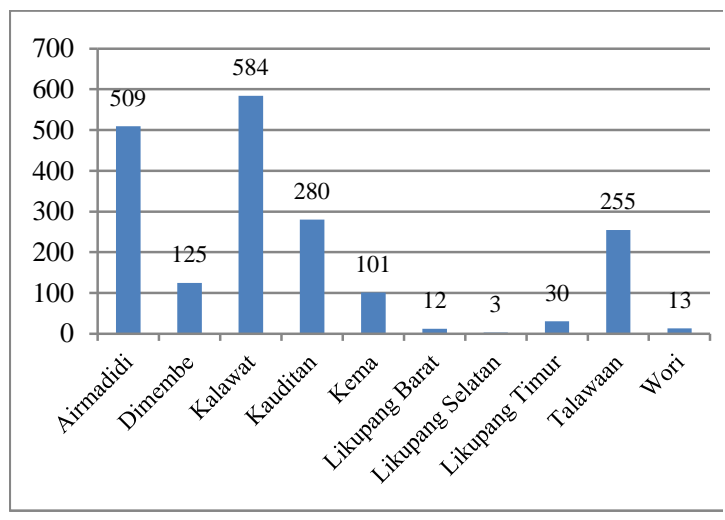

Gambar 2. Luas Alih Fungsi Lahan Berdasarkan Kecamatan Tahun 2014

Sedangkan kecamatan yang luas alih fungsi lahan pertaniannya mengalami penurunan adalah di Kecamatan Likupang Selatan sebesar tiga hektar.

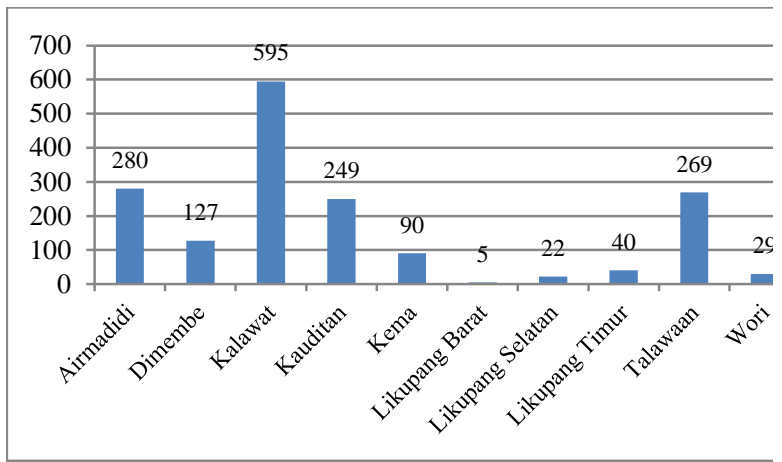

Gambar 3. Luas Alih Fungsi Lahan Menurut Kecamatan Tahun 2015

Gambar 3 menunjukkan bahwa luas alih fungsi lahan pertanian di Kabupaten Minahasa Utara pada tahun 2015. Kecamatan Kalawat masih menempati posisi tertinggi diikuti oleh Kecamatan Talawaan dan Airmadidi, bahkan luas alih fungsinya terus meningkat dari tahun ke tahun. Kecamataan Airmadidi yang biasanya menempati ranking 2 pada tahun 2013 dan 2014 telah digeser oleh Kecamatan Talawaan yang meningkat ke peringkat kedua. Dibandingkan dengan tahun 2014, maka Kecamatan Airmadidi mengalami penurunan yang cukup signifikan, dari 509 hektar menjadi 280 hektar atau sebesar 229 hektar (44.99 $\%$ ), sementara tergolong cukup tinggi, sedangkan Kecamatan Talawaan meningkat sebesar 14 hektar dari 255 hektar pada tahun 2014 menjadi 269 hektar pada tahun 2015.

Gambar 4 menunjukkan luas alih fungsi lahan pertanian di Kabupaten Minahasa Utara pada tahun 2015. Terlihat bahwa hampir semua kecamatan luas alih fungsi lahan pertanian meningkat dengan pesat kecuali Kecamatan Dimembe dan Wori, namun Kecamatan Kalawat, Airmadidi dan Talawaan masih menempati posisi tiga teratas. Sedangkan kecamatan dengan luas alih fungsi lahan pertanian yang terendah masih tetap pada Kecamatan Likupang Barat. Sedangkan kecamatan dengan luas alih fungsi lahan pertanian terendah yang biasanya ditempati oleh Kecamatan Likupang Selatan, untuk tahun 2015 berada pada Kecamatan Likupang Barat.

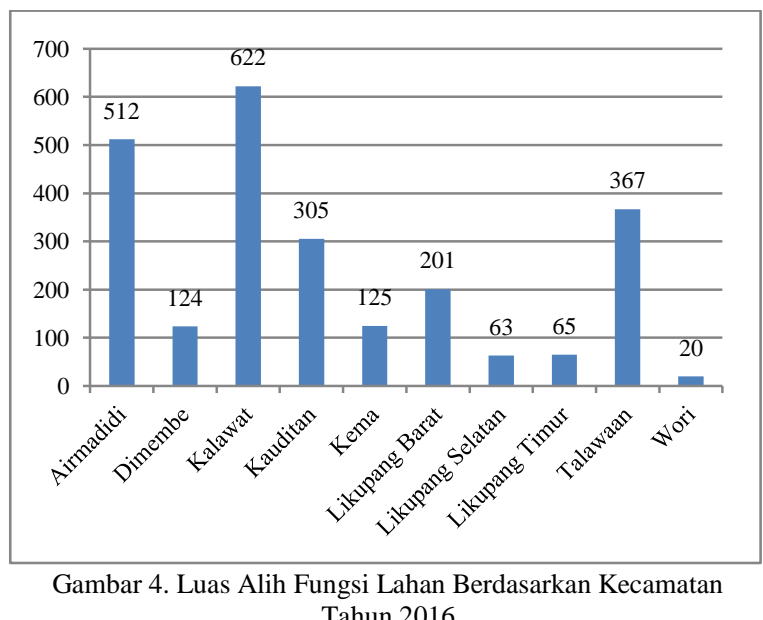

\section{Rekapitulasi Alih Fungsi Lahan}

Perubahan penggunaan lahan di Kabupaten Minahasa Utara menyebabkan berubahnya fungsi lahan tersebut dari lahan pertanian menjadi lahan non pertanian. Hal ini tidak terlepas dari posisi wilayahnya yang strategis menyebabkan kegiatan ekonominya terus meningkat serta ditambah lagi dengan meningkatnya jumlah penduduk di daerah ini. Gambar 6 menunjukan rekapitulasi alih fungsi lahan pertanian di Kabupaten Minahasa Utara berdasarkan lima Kecamatan tertinggi Tahun 2013-2016. 


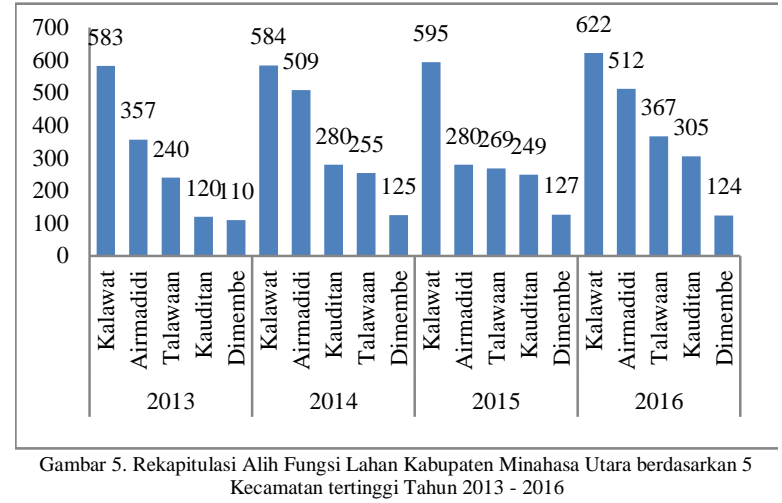

Sejak tahun 2013 hingga 2016, lima kecamatan yang menempati peringkat teratas adalah Kecamatan Kalawat, Airmadidi, Talawaan, Kauditan dan Dimembe. Urutan ini tidak berubah, kecuali pada tahun 2014, Kecamatan Kauditan lebih tinggi atau berada di posisi kedua menggeser posisi Kecamatan Talawaan. Hal ini disebabkan karena meningkatnya realisasi pembebasan lahan di wilayah ini untuk pembangunan jalan tol Manado-Bitung.

\section{Tren Luas Alih Fungsi Lahan Pertanian ke Non Pertanian Tahun 2013hingga 2016}

Perkembangan luas alih fungsi lahan pertanian ke non pertanian Kabupaten Minahasa Utara dari tahun 2013 hingga tahun 2016 cenderung meningkat. Pada tahun 2013 ke 2014, luas alih fungsi lahan pertanian ke non pertanian sebesar 1,77 persen, kemudian pada tahun 2014 ke 2015 terus meningkat dengan persentase yang semakin besar yaitu 9,97 persen.

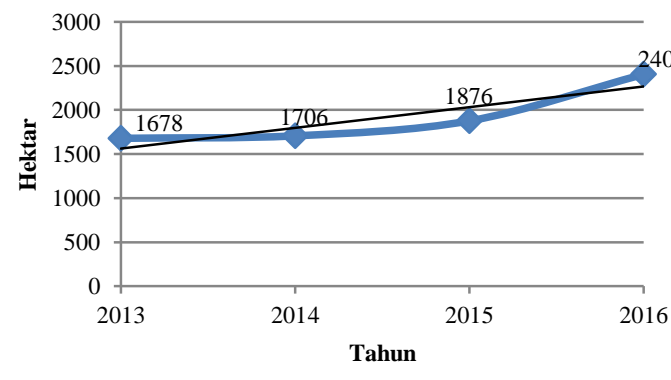

Gambar 6. Tren Ahli Fungsi Lahan di Kabupaten Minahasa Utara Tahun 2013-2016
Pada tahun 2015 ke 2016, perkembangan luas alih fungsi lahan pertanian semakin meningkat menjadi 28,2 persen atau meningkat 35,35 persen lebih besar dari tahun 2015 .

\section{KESIMPULAN DAN SARAN}

\section{Kesimpulan}

Berdasarkan hasil dan pembahasan, maka dapat disimpulkan bahwa luas alih fungsi lahan pertanian ke non pertanian di Kabupaten Minahasa Utara pada Tahun 2013 hingga Tahun 2016 cenderung meningkat.

\section{Saran}

Alih fungsi lahan semakin meningkat akan membuat lahan pertanian semakin menyempit, sehingga Pemerintah Kabupaten Minahasa Utara harus lebih memberikan perhatian yang serius terhadap masalah alih fungsi lahan pertanian ke non pertanian. Untuk penelitian selanjutnya disarankan untuk meneliti faktor-faktor yang mempengaruhi alih fungsi lahan pertanian.

\section{DAFTAR PUSTAKA}

Adi, Sasono. 1995. Ekonomi Politik Penguasaan Tanah. Pustaka Sinar Harapan, Jakarta.

Akbar, R. 2008. Proses Pembebasan Tanah Pertanian Untuk Pembangunan Kawasan Perumahan. Fakultas Pertanian. Institut Pertanian Bogor.

A.Tohir, Kaslan. 2000 Seuntai Pengetahuan Usaha Tani Indonesia.Rineka Cipta. Jakarta.

Adisasmita. H. R, 2005. Dasar-dasar Ekonomi Wilayah. Jakarta. Graha Ilmu.

Puspasari, Aneke. 2012. Faktor-Faktor Yang Mempengaruhi Alih Fungsi Lahan Pertanian. Skripsi Fakultas Ekonomi Dan Manajemen. Institut Pertanian Bogor. 
Arsyad, Lincolin. 2004. Pengantar Perencanaan Pembangunan Ekonomi Daerah. Yogyakarta: BPFE Yogyakarta.

Arsyad, S. 2010. Konsevarsi Tanah dan Air. Edisi Kedua. IPB. Bogor.

Boediono. 2005. Teori Pertumbuhan Ekonomi. Yogyakarta: BPFE.

Daniel, Moehar. 2002. Pengantar Ekonomi Pertanian. Jakarta. PT. Buni Aksara.

Hanafie, Rita. 2010. Pengantar Ekonomi Pertanian. CV Andi. Yogyakarta.

Irawan, Bambang. 2002. Dampak Konversi Lahan Pertanian. Bogor.

Iqbal, N. 2007.Strategi Pengendalian Alih Fungsi Lahan Pertanian Bertumpu Pada Partisipasi Masyarakat. Pusat Analisis Sosial Ekonomi dan Kebijakan Pertanian. Bogor.

Jhingan, M. L, 2007. Ekonomi Pembangunan dan Perencanaan. Jakarta. PT Raja Grafindo Persada.

Jonathan, Sarwono. 2006. Metode Penelitian Kuantitatif dan Kualitatif. Yogyakarta:Graha Ilmu.

Lestari, T. 2009. Dampak Konversi Lahan Pertanian Bagi taraf Hidup Petani. Skripsi. Departemen Sains Komunikasi dan Pengembangan Masyarakat. Institut Pertanian Bogor.

Mokoagow, Marla. 2012. Faktor-Faktor Yang Mempengaruhi Alih Fungsi Lahan Pertanian Ke Non Pertanian Di Kabupaten Minahasa Utara. Skripsi. Fakultas Pertanian. Manado.

Mustopa, Z.2011. Analisis Faktor-Faktor Yang Mempengaruhi Alih Fungsi Lahan Pertanian di Kabupaten Demak. Skripsi. Universitas Diponegoro. Semarang.
Nasution. 2000. Masalah Alih Fungsi Lahan Dan Dampaknya Terhadap Keberlangsungan Swasembada Pangan. Pusat Penelitian Sosial Ekonomi Pertanian. Jakarta.

Pambudi, A. 2008. Analisis Nilai Ekonomi Lahan Pada Lahan Pertanian Dan Pemukiman di Kecamatan Ciampa Kabupaten Bogor. Skripsi. Institut Pertanian Bogor. Bogor.

Poppy, Haryani.2011. Perubahan Penutup Penggunaan Lahan dan Perubahan. Bandung: Penerbit Andi.

Ruswandi. 2009. Alih Lahan Fungsi Pertanian. Jakarta : Graha Ilmu.

Sjafrizal. 2008. Ekonomi Regional. Teori dan Aplikasi. Padang: Baduose Media.

Solihah, Neneng. 2002. Dampak Alih Fungsi Lahan Sawah Ke Penggunaan Non Sawah Terhadap Pendapatan Petani Di Kabupaten Bogor. Skripsi. Bogor: Fakultas Pertanian Institut Pertanian Bogor.

Sugiyono. 2008. Metode Penelitian Kuantitatif Kualitatif dan R\&D. Bandung Alfabeta.

Sukirno, Sodono.2006. Ekonomi Pembangunan Proses, Masalah, dan Dasar Kebijakan. Kencana :Lembaga Penerbit Penata Media Gruop. Jakarta

Sulistyawati, D, A. 2014. Analisis Dampak Alih Fungsi Lahan Pertanian Terhadap Ketahananan Pangan Di Kabupaten Cianjur. Skripsi. Departemen Ekonomi Sumberdaya Dan Lingkungan. Fakultas Ekonomi dan Manajemen Institut Pertanian Bogor. 
Tambunan Tulus. 2003. Perkembangan Sektor Perekonomian di Indonesia. Ghalia Indah. Jakarta.
Todaro, Michael P. 2010. Ekonomi Pembangunan. Erlanggga. Jakarta.

Utomo, W. H, 2002. Konservasi Tanah. IKIP Malang, Malang. 